Вісник Львівського торговельно-економічного університету. Економічні науки. 2019. Вип. 57.

\title{
УДК 338.486.4
}

Миронов Ю. Б., ORCID ID: 0000-0002-9015-506X, Researcher ID: E-9613-2019,

к.е.н., дои., доцент кафедри туризму та готельно-ресторанної справи, Львівський торговельно-економічний університет, м. Львів

Миронова М. I.,

ORCID ID: 0000-0003-1438-4394,

к.е.н., доцент кафедри теоретичної та прикладної економіки, Львівський торговельноекономічний університет, м. Львів

\section{МЕТОДОЛОГІЧНІ ПІДХОДИ ДО ОЦІНЮВАННЯ ЕКОНОМІЧНОЇ ЕФЕКТИВНОСТІ ІНДУСТРІї ТУРИЗМУ ТА ТУРИСТИЧНОГО БIЗНECУ}

\begin{abstract}
Анотація. У статті розглядається сутність понять “економічна ефективність", “ефективність індустрії туризму”, визначено передумови розроблення методологічного підходу до оиінювання економічної ефективності функиіонування сфери туризму, охарактеризовано економічну сторону оцінювання ефективності сфери туризму. Порушується проблема розробки сукупності показників для оиінювання економічної ефективності сфери туризму на основі комплексного підходу. Запропоновано алгоритм оцінювання економічної ефективності індустрії туризму та показники такого оцінювання. Описано технологію розрахунку інтегрального показника економічної ефективності індустрії туризму. Представлено модель оиінювання економічної ефективності діяльності підприсмств туристичного бізнесу. Доведено, що адекватна оиінка економічної ефективності сфери туризму дозволяс активно впливати на поточний стан і тенденції розвитку туристичної галузі, відслідковувати і коректувати некеровані явища і процеси, складати плани та програми розвитку сфери туризму як на регіональному, так $і$ на державному рівні. Визначено перспективні напрями подальщих наукових досліджень у даному напрямі.
\end{abstract}

Ключові слова: туризм, туристичний бізнес, індустрія туризму, ефективність, економічна ефективність.

Myronov $Y$. B.,

Ph.D., Associate Professor, Associate Professor of the Department of Tourism and Hotel\&Restaurant Business, Lviv University of Trade and Economics, Lviv

Myronova M. I.,

Ph.D., Associate Professor of the Department of Theoretical and Applied Economics, Lviv University of Trade and Economics, Lviv

\section{METHODOLOGICAL APPROACHES TO EVALUATION OF THE TOURISM INDUSTRY AND TOURIST BUSINESS ECONOMIC EFFICIENCY}

\footnotetext{
Abstract. The essence of the concepts of "economic efficiency", "efficiency of the tourism industry" is considered in the article, the preconditions of the development of the methodological approach to the economic efficiency evaluation of the tourism sphere functioning are defined as well as the economic side of the evaluation of the tourism sphere's efficiency is characterized. The problem of developing a set of indicators for assessing the tourism sector economic efficiency based on the integrated approach is highlighted. The algorithm of evaluation of economic efficiency of tourism industry and indicators of such estimation are proposed. The technology of calculating the integral indicator of economic efficiency of the tourism industry is described. The model of economic efficiency evaluation of tourist business enterprises activity is presented.
} 
Вісник Львівського торговельно-економічного університету. Економічні науки. 2019. Вип. 57.

It is proved that an adequate assessment of the economic efficiency of the tourism sector can actively influence the current state and trends of the tourism industry, track and correct unmanaged phenomena and processes, help to draw up plans and programs for the tourism sector development both at the regional and at the state level. The perspective directions of further scientific researches in this direction are determined.

Key words: tourism, tourism business, tourism industry, efficiency, economic efficiency.

JEL Classification: C52; D61; L83

\section{DOI: https://doi.org/10.36477/2522-1205-2019-57-11}

Постановка проблеми. Індустрія туризму здійснюе позитивний вплив на розвиток різних галузей економіки України (транспорт, зв'язок, виробництво товарів народного споживання та ін.), будучи каталізатором економічного розвитку туристичних дестинацій. При державному регулюванні сфери туризму постійно виникає необхідність визначення економічних показників очікуваних результатів реалізації регіональних та національних програм розвитку туризму. За умов конкуренції та прагнення підприємств до економічного розвитку все більшого значення набуває оцінювання економічної ефективності туристичних підприємств, адже практика функціонування ринку туристичних послуг показує, що без аналізу економічної ефективності туристичний бізнес не може нормально функціонувати, а туристичне підприємство - досягати мети діяльності та реалізовувати свою місію.

Аналіз останніх досліджень i публікацій. Проблемні аспекти оцінювання економічної ефективності індустрії туризму неодноразово піднімалися у працях українських та іноземних вчених, серед яких С. Гатаулліна [2], Н. Рубцова [4; 10], О. Порошина [9], В. Славін [11], А. Топчій [2]. Проблематиці оцінювання економічної ефективності туристичного бізнесу на мікроекономічному рівні присвячено наукові публікації Р. Балашової [1], І. Димеденко [5], К. Єсіпової [6], С. Мельниченко [6]. У працях цих вчених досліджено методи оцінювання ефективності діяльності туристичних підприємств та туристичної діяльності в регіоні, вивчено підходи до оцінювання ефективності розвитку сфери туризму. Разом із тим, багато теоретичних та практичних аспектів проблеми оцінювання ефективності сфери туризму розкриті поки недостатньо повно та потребують грунтовнішого опрацювання.

Постановка завдання. Метою статті $\epsilon$ формування методологічних підходів до оцінювання економічної ефективності індустрії туризму загалом та ефективності діяльності туристичних підприємств зокрема.

Виклад основного матеріалу дослідження. Вплив туристичної галузі на економіку характеризується мультиплікативним ефектом. За умов постійно зростаючого впливу туристичної індустрії на економічну та соціальну сфери суспільства виникає необхідність адекватного оцінювання ефективності функціонування індустрії туризму, а також окремих туристичних бізнесів. Оцінювання економічної ефективності туристичної індустрії вимагає формування системи показників, які б характеризували економічний ефект існуючих та перспективних заходів у цій сфері, продуктивність використання туристичних ресурсів дестинації.

Під економічною ефективністю ми розуміємо сукупну оцінку економічних результатів (доходів, прибутку) відносно до встановлених цілей та затрат на їх досягнення.

При розгляді сутності поняття “ефективність індустрії туризму" важливо розуміти, що туристичний бізнес не можна зводити лише до надання туристичних послуг, оскільки цей вид діяльності визначається не стільки обсягом конкретно наданих послуг, скільки кількістю споживачів туристичного продукту, а ефект в індустрії туризму залежить від кінцевого споживання будь-якого ії продукту [11].

За сучасних умов функціонування та розвитку індустрії туризму іiі ефективність також доцільно розглядати у контексті взаємодії та взаємокоординації суб'єктів сфери туризму та рекреації учасників ланцюжка створення цінності туристичного продукту, оскільки соціально-економічна ефективність такого ланцюжка залежить не стільки від результату автономного функціонування кожного суб'єкта туристичної діяльності, скільки від їх взаємної координації та кооперації, тобто ефективності взаємодії [8].

Розроблення методологічного підходу до дослідження економічної ефективності функціонування сфери туризму доцільно почати, на нашу думку, 3 визначення об'єкта, предмета дослідження і методичного інструментарію оцінювання. Об'єкт дослідження у даному випадку - туристична діяльність, під якою ми розуміємо вид господарсько-економічної діяльності, результатом якої $є$ створення туристичного продукту. Предметом дослідження $є$ економічна ефективність індустрії туризму. Особливістю практичного застосування цього підходу повинна стати доцільність його використання на національному, регіональному чи мікроекономічному рівнях господарювання.

Пропонований алгоритм оцінювання економічної ефективності індустрії туризму включає таку послідовність дій [7, с. 322]:

1) визначення потреби в інформації, вибір та обгрунтування показників, що характеризують економічний аспект функціонування сфери туризму;

2) збирання та обробка вихідних даних;

3) аналіз отриманих даних та прийняття управлінських рішень.

Дослідниками сфери туризму пропонуються різні підходи до формування переліку показників, які характеризують різноманітні аспекти 
Вісник Львівського торговельно-економічного університету. Економічні науки. 2019. Вип. 57.

ефективності функціонування індустрії туризму. Проблема розробки сукупності показників для оцінювання економічної ефективності сфери туризму може бути вирішена при комплексному підході, який охоплює всі складові економічного потенціалу та зовнішнього середовища функціонування туристичної індустрії, результативність їх використання з одночасним переходом від загального явища до конкретних показників.

Економічна сторона оцінювання ефективності сфери туризму передбачає характеристику потенційних можливостей здійснення процесів виробництва та збуту туристичних продуктів, виражена через динаміку та результативність цих процесів, що підтверджує економічну доцільність ведення туристичної діяльності чи створення певної туристично-рекреаційної системи [9, с. 84].

В якості показників соціально-економічної ефективності сфери туризму можна використовувати такі:

1) частка галузі туризму у ВВП країни, \%;

2) кількість туристів на 1000 осіб населення, oc.;

3) кількість туристів на одиницю місткості всіх місць розміщення, включаючи спеціальні, осіб/місце;

4) інвестиції в основний капітал у розвиток колективних засобів розміщення, млн грн;

5) коефіцієнт використання номерного фонду;

6) кількість місць в об’єктах громадського харчування на 1000 осіб населення, місць;

7) оборот громадського харчування на душу населення, грн/ос.

Після збору (а в разі необхідності - розрахунку) статистичних показників обчислюється інтегральний показник економічної ефективності індустрії туризму $\left(e_{i}\right)$ по всьому переліку критеріїв:

$$
e_{i}=\sum_{i=1}^{n} k_{i} p_{i}
$$

де $p_{i}-i$-ий показник соціально-економічної ефективності сфери туризму;

$k_{i}$ - вагомість $i$-го показника в інтегральному показнику;

$n$ - кількість показників.
Для визначення вагомості $i$-го показника $k_{i}$ використаємо підхід, базований на розрахунку вагових показників за коефіцієнтами парної кореляції між ними [10, с. 127-128].

Якщо $r_{i j}$ - коефіцієнт парної кореляції між $i$-м та $j$-м показниками, то вагові коефіцієнти $\left(k_{i}\right)$ визначаються за такою формулою:

$$
k_{i}=\frac{\sum_{j=1}^{n} r_{i j}}{\sum_{j=1}^{n} \sum_{i=1}^{n} r_{i j}} .
$$

Сума коефіцієнтів парної кореляції кожного показника 3 іншими співвідноситься із загальною сумою коефіцієнтів по всій матриці коефіцієнтів парної кореляції. В силу того, що остання характеризує взаємозв'язок між усіма показниками, то отримані величини $k_{i}$ відображають питому вагу $i$-го показника в інтегральному показнику ефективності по всьому блоку показників. Такий підхід, на нашу думку, у даному випадку виправданий, оскільки показники характеризують одну і ту ж складову ефективності індустрії туризму з економічної сторони.

Економічну ефективність діяльності туристичного бізнесу на мікроекономічному рівні можна здійснювати за такою моделлю (рис. 1).

Визначення економічної ефективності туристичного продукту проводиться на основі розрахунку наступних економічних показників:

- доходи від реалізації туристичного продукту;

- прямі та змінні витрати на виробництво турпродукту;

- маржинальний дохід (постійні витрати плюс прибуток) від реалізації туристичного продукту;

- поточні витрати та витрати на збут турпродукту;

- валовий прибуток;

- чистий прибуток від реалізації туристичного продукту.

Враховуючи досвід авторів [1; 3], доцільно використовувати таку логічну схему оцінювання економічної ефективності туристичного підприємства (рис. 2).

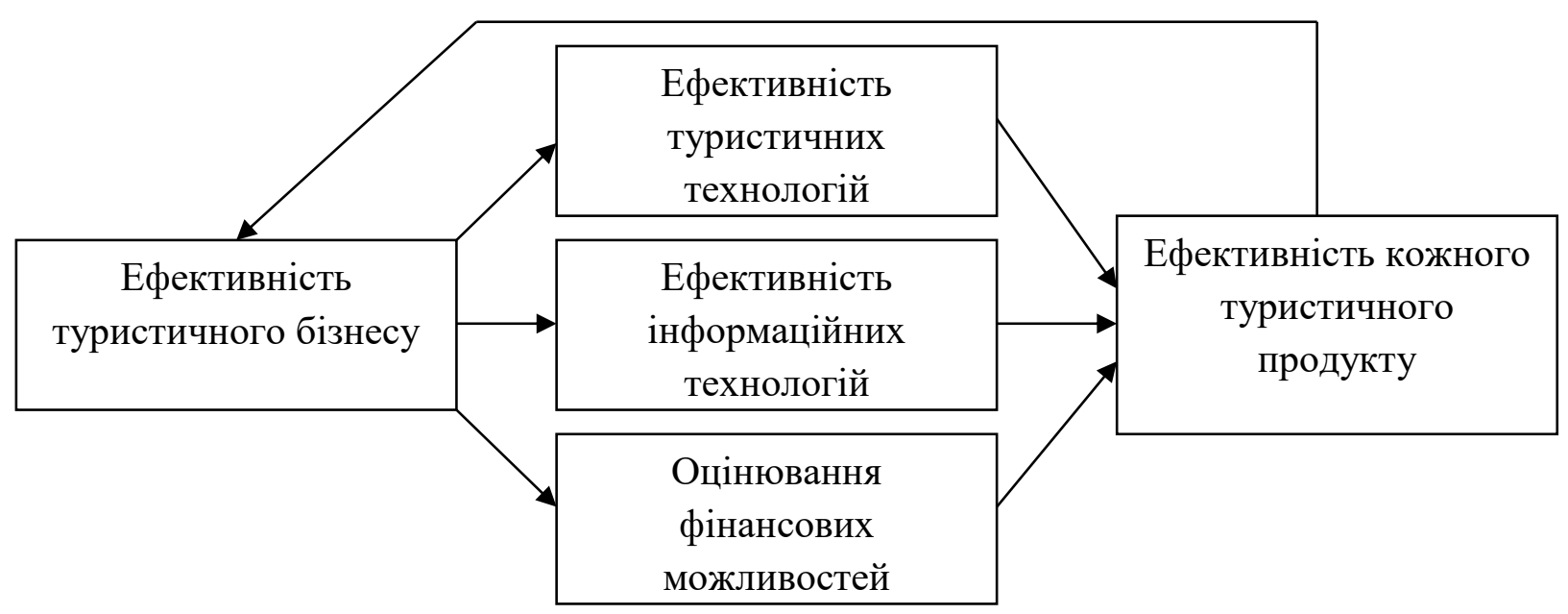

Рис. 1. Комплексне оцінювання ефективності діяльності туристичного підприємства (побудовано авторами на основі [1]) 
Вісник Львівського торговельно-економічного університету. Економічні науки. 2019. Вип. 57.

\begin{tabular}{|c|c|c|c|c|c|c|}
\hline 1 & 2 & 3 & \multicolumn{2}{|c|}{4} & 5 & 6 \\
\hline \multirow[t]{2}{*}{$\begin{array}{c}\text { Вибір методів } \\
\text { оцінювання }\end{array}$} & $\begin{array}{c}\text { Вибір } \\
\text { показників }\end{array}$ & $\begin{array}{c}\text { Кількісне } \\
\text { оцінювання } \\
\text { критеріїв }\end{array}$ & $\begin{array}{l}\text { Роз } \\
\text { пок }\end{array}$ & $\begin{array}{l}\text { унок } \\
\text { Іиків }\end{array}$ & $\begin{array}{c}\text { Аналіз та } \\
\text { оцінювання } \\
\text { результатів }\end{array}$ & $\begin{array}{l}\text { Підготовка } \\
\text { пропозицій }\end{array}$ \\
\hline & & $\begin{array}{r}\text { клю } \\
\text { пока }\end{array}$ & $\begin{array}{l}\text { ві } \\
\text { Іки }\end{array}$ & $\begin{array}{r}\text { інте } \\
\text { по }\end{array}$ & $\begin{array}{l}\text { ЛЬний } \\
\text { ник }\end{array}$ & \\
\hline
\end{tabular}

\section{Рис. 2. Логічна схема оцінювання економічної ефективності туристичного підприємства} (побудовано на основі $[1 ; 3])$

Логічна схема методу оцінювання економічної ефективності туристичного підприємства (рис. 2) передбачає:

1) вибір методів виміру та кількісного оцінювання;

2) вибір та обгрунтування системи показників;

3) кількісне оцінювання критеріїв (на основі коефіцієнтів);

4) розрахунок показників (ключових i/aбо інтегрального);

5) аналіз та оцінювання результатів оцінювання;

6) підготовка пропозицій на основі одержаних оцінок, прийняття управлінських рішень.

За такою схемою можливо не тільки оцінити ефективність роботи туристичного підприємства, його структурних підрозділів, а й визначити пріоритетні напрями діяльності, стратегію розвитку, розробити прогноз та план дій на перспективу, встановити результати використання факторів виробництва (у т. ч. інформації).

Для якісного оцінювання та прогнозування економічної ефективності туристичного бізнесу можливим $\epsilon$ використання методу експертного оцінювання (методу Дельфи), SWOT-аналізу, матриці БКГ та ін.

Висновки та перспективи подальших досліджень у даному напрямі. Таким чином, адекватна оцінка економічної ефективності сфери туризму дозволяє активно впливати на поточний стан i тенденції розвитку туристичної галузі, відслідковувати і коректувати некеровані явища і процеси, складати плани та програми розвитку сфери туризму як на регіональному, так і на державному рівні. Окрім цього, підвищення якості реалізації державної політики у сфері туризму дозволить покращити туристичну та інвестиційну привабливість туристичної дестинації. Великого значення набуває оцінювання економічної ефективності туристичних підприємств, адже без належного аналізу економічної ефективності неможливо приймати ефективні управлінські рішення та досягати мети туристичного бізнесу.

Перспективним для подальших досліджень, на наш погляд, $\epsilon$ розроблення єдиної методології оцінювання економічної ефективності сфери туризму та діяльності туристичних підприємств, що дозволить користуватися визначеними (стандартними) показниками та критеріями оцінювання при проведенні різноманітних досліджень сфери туризму, зокрема, із застосуванням сучасних інформаційних технологій.

\section{ЛІТЕРАТУРА}

1. Балашова Р. І. Розвиток методів оцінки ефективності діяльності туристичних підприємств / Р. І. Балашова // Вісник ДІТБ. - 2008. - № 12. C. 99-108. - (Серія: Економіка, організація та управління підприємствами туристичної індустрії та туристичної галузі в цілому).

2. Гатауллина С. Ю. О состоянии методического обеспечения оценки экономической эффективности туристской деятельности в регионе / С. Ю. Гатауллина, А. В. Топчий // Науковедение : Интернет-журнал. - 2014. - № 4 (23). [Электронный pecypc]. - Режим доступа : https://naukovedenie.ru/PDF/31EVN414.pdf.

3. Глищенко А. Н. Экономическая результативность деятельности предприятий : монография / А. Н. Глищенко, Н. А. Кизим, Я. В. Догадайло. - Х. : ИНЖЭК, 2005. - 144 с.

4. Даниленко Н. Н. Обоснование инновационных аспектов методологии оценки эффективности туризма / Н. Н. Даниленко, Н. В. Рубцова // Сервис в России и за рубежом. - 2012. - № 6. - С. 69-78.

5. Димеденко I. В. Методичні підходи до аналізу ефективності діяльності підприємств туристичного бізнесу / І. В. Димеденко // Вісник ДІТБ. - 2009. - № 13. - С. 41-46. - (Серія: Економіка, організація та управління підприємствами туристичної індустрії та туристичної галузі в цілому).

6. Мельниченко С. В. Оцінка ефективності бізнес-процесів туристичних підприємств / С. В. Мельниченко, К. А. Єсіпова // Вісник Чернівецького торговельно-економічного інституту. Економічні науки. - 2012. - Вип. 4 (48). - С. 222-229.

7. Миронов Ю. Б. Оцінка економічної ефективності індустрії туризму / Ю. Б. Миронов, М. І. Миронова // Інновації в управлінні асортиментом, якістю та безпекою товарів і послуг : матеріали 
Вісник Львівського торговельно-економічного університету. Економічні науки. 2019. Вип. 57.

IV Міжнар. наук.-практ. конф. (м. Львів, 24 листопада 2016 р.). - Львів : Растр-7, 2016. - 376 с. C. 321-324.

8. Морозов М. А. Социально-экономическая эффективность туристской деятельности: современные подходы к исследованию / М. А. Морозов, Н. В. Рубцова // Электронный научный журнал Байкальского государственного университета. - 2016. T. 7. - № 2. [Электронный ресурс]. - Режим доступа : http://eizvestia.isea.ru/pdf.aspx?id=20676.

9. Порошина О. В. Оценка эффективности развития сферы туризма на основе целеориентированного подхода / О. В. Порошина // Проблемы развития территории. - 2016. - № 1. - С. 75-95.

10. Рубцова Н. В. Социально-экономическая эффективность туристской деятельности: теория, методология, практика : монография / Н. В. Рубцова. - Иркутск : Издательство БГУЭП, 2015. - 212 с.

11. Славин В. В. Оценка эффективности функционирования сферы туризма / В. В. Славин // ЭГО: экономика, государство, общество. - 2012. Вып. 1. [Электронный ресурс]. - Режим доступа : http://ego.uapa.ru/ru/issue/2012/03/05/.

\section{REFERENCES}

1. Balashova, R. I. (2008), Rozvytok metodiv otsinky efektyvnosti diialnosti turystychnyh pidpryiemstv, Visnyk DITB. Ekonomika, orhanizatsiia ta upravlinnia pidpryiemstvamy turystychnoi haluzi $\mathrm{v}$ tsilomu, 12, pp. 99-108.

2. Gataullina, S. Iu and Topchiy, A. V. (2014), O sostoianii metodicheskogo obespecheniia jtsenki ekonomicheskoi effektivnosti turistskoi deiatelnosti v regione, Naukovedeniie, 4 (23), available at: https://naukovedenie.ru/PDF/31EVN414.pdf (Accessed Mar 14, 2019).

3. Glishchenko, A. N., Kizim, N. A. and Dogadailo, Ia. V. (2005), Ekonomicheskaia rezultativnost deiatelnosti predpriiatij: monografiia, Kharkov, Inzhek, 144 p.
4. Danilenko, N. N. (2012), Obosnovaniie innovatsionnykh aspektov metodologii otsenki effektivnosti turizma, Servis v Rossii i za rubezhom, 6, pp. 69-78.

5. Dymedenko, I. V. (2009), Metodychni pidkhody do analizu efektyvnosti diialnosti pidpryiemstv turystychnoho biznesu, Visnyk DITB. Ekonomika, orhanizatsiia ta upravlinnia pidpryiemstvamy turystychnoi haluzi v tsilomu, 13, pp. 41-46.

6. Melnychenko, S. V. and Iesipova, K. A. (2012), Otsinka efektyvnosti biznes-protsesiv turystychnykh pidpryiemstv, Visnyk Chernivetskoho torhovelnoekonomichnoho instytutu. Ekonomichni nauky, 4 (48), pp. 222-229.

7. Myronov, Yu. B. and Myronova, M. I. (2016), Otsinka ekonomichnoii efektyvnosti industrii turyzmu, Innovatsii $\mathrm{v}$ upravlinni asortymentom, iakistiu ta bezpekoiu tovariv i posluh: Conference Proceedings of the IV International Conference (Lviv, November 24, 2016), Lviv, Rastr-7, pp. 321-324.

8. Morozov, M. A. and Rubtsova, N. V. (2016), Socialno-ekonomicheskaia effektivnost turistskoi deiatelnosti: sovremennyie podkhody $\mathrm{k}$ issledovaniiu, Elektronnyi nauchnyi zhurnal Baikalskogo gosudarstvennogo universiteta, vol. 7, issue 2, available at: http://eizvestia.isea.ru/pdf.aspx?id=20676 (Accessed Mar 14, 2019).

9. Poroshina, O. V. (2016), Otsenka effektivnosti razvitiia sfery turizma na osnove tseleoriienirovannogo podkhoda, Problemy razvitiia territorii, 1, pp. 75-95.

10. Rubtsova, N. V. (2015), Sotsialno-ekonomicheskaiia effektivnost turistskoi deiatelnosti: teoriia, metodologiia, praktika: monografiia, Irkutsk, Izdatelstvo BGUEP, $212 \mathrm{p}$.

11. Slavin, V. V. (2012), Otsenka effektivnosti funktsionirovaniia sfery turizma, EGO: ekonomika, gosudarstvo, obshchestvo, 1, available at: http://ego.uapa.ru/ru/issue/2012/03/05/ (Accessed Mar 14, 2019).

Стаття надійшла до редакиії 15 січня $2019 p$. 